University of Nebraska - Lincoln

DigitalCommons@University of Nebraska - Lincoln

July 2001

\title{
The Effect of Ethanol and Acetate on Protein Expression in Pichia pastoris
}

MEHMET INAN

MICHAEL M. MEAGHER

Follow this and additional works at: https://digitalcommons.unl.edu/chemengbiochemeng

Part of the Biochemical and Biomolecular Engineering Commons

INAN, MEHMET and MEAGHER, MICHAEL M. , "The Effect of Ethanol and Acetate on Protein Expression in Pichia pastoris" (2001). Papers in Biochemical Engineering. 15.

https://digitalcommons.unl.edu/chemengbiochemeng/15

This Article is brought to you for free and open access by the Chemical and Biomolecular Engineering Research and Publications at DigitalCommons@University of Nebraska - Lincoln. It has been accepted for inclusion in Papers in Biochemical Engineering by an authorized administrator of DigitalCommons@University of Nebraska - Lincoln. 


\title{
The Effect of Ethanol and Acetate on Protein Expression in Pichia pastoris
}

\author{
MEHMET INAN $^{1}$ and MICHAEL M. MEAGHER ${ }^{1 *}$ \\ Biological Process Development Facility, Department of Chemical Engineering, University of Nebraska-Lincoln, \\ Lincoln, Nebraska 68583-0919, USA
}

Received 11 October 2000/Accepted 25 July 2001

\begin{abstract}
Pichia pastoris is an excellent host for high-level heterologous gene expression, but there is still much interest in improving the productivity of recombinant protein production. $P$. pastoris produces a small amount of ethanol as a by-product during the glycerol fed-batch phase and the mixed-feed induction phase (glycerol-methanol) of high cell density fermentations, regardless of the phenotype (Mut ${ }^{+}$, Mut $t^{\mathrm{s}}$ or $\mathrm{Mut}^{-}$). We have investigated ethanol repression of the $A O X 1$ promoter using strains, GS115 $\left(\mathrm{Mut}^{+}\right)$and $\mathrm{MC100-3}\left(\mathrm{Mut}^{-}\right)$, expressing an $A O X 1-$ lac $Z$ fusion. The addition of $10 \mathrm{mg}^{-1}$ ethanol at the start of methanol induction delayed $\beta$-galactosidase production and methanol utilization for four hours in shake flask experiments. When ethanol and acetate were added together, all of the ethanol was converted to acetate, which also represses the $A O X 1$ promoter. The effects of ethanol and acetate on protein expression in $P$. pastoris at shake flask and fermentor conditions are discussed.
\end{abstract}

[Key words: Pichia pastoris, carbon catabolite repression, $A O X 1$ promoter, alcohol oxidase regulation]

Pichia pastoris, a methylotrophic yeast, is a host for the production of heterologous proteins of commercial interest. Some of the factors that make $P$. pastoris a popular expression system are; its ability to grow to very high cell densities in a defined media, the presence of a strong inducible alcohol oxidase promoter $(A O X 1)$, and the availability of the Pichia expression system in a commercially available kit from Invitrogen Corporation (Carlsbad, CA, USA) (1).

The methylotrophic yeast, including the genera Candida and Pichia, have a general methanol utilization pathway, and many of the enzymes are compartmentalized in methanol induced microbodies (i.e., peroxisomes, and the cytoplasm) (2). Methylotrophic yeasts, similar to other yeasts, are also capable of utilizing glycerol, ethanol and acetate.

For the production of heterologous proteins in fermentor cultures of $P$. pastoris, a three-stage, high cell density fermentation scheme is normally employed. In the first stage, the recombinant yeast is cultured in a salt medium on a nonfermentable carbon source, such as glycerol. Upon glycerol depletion, the second phase (transition phase) is initiated by adding glycerol at a growth-limiting rate. The second phase is important since by-products (e.g., ethanol), generated during batch phase are consumed and cells are primed for induction. The third phase (the induction phase) is initiated by adding limited concentrations of methanol, which results in recombinant protein production (3). Alternatively mixedfeed, fed-batch fermentations have been used with Mut ${ }^{-}$, Muts $^{\text {s }}(4)$ and Mut (5) strains of $P$. pastoris. While mixed feed fermentations may leads to increase in overall productivity, maximum level of protein is not reached because re-

\footnotetext{
* Corresponding author. e-mail: mmmeaghe@unlnotes.unl.edu
} phone: $+1-402-472-2342$ fax: $+1-402-472-1693$ sidual glycerol partially represses the $A O X I$ promoter (4).

Though a majority of the work in this work was conducted in shake flask, preliminary fermentation studies at the $5-l$ scale were performed. A high feed rate $(7 \mathrm{~g} / l / \mathrm{h})$ of glycerol with a Mut strain resulted in the production of ethanol and acetate. Therefore, we studied the effect of addition of ethanol and acetate during the induction phase of fed-batch fermentation.

\section{MATERIALS AND METHODS}

Strains $P$ pastoris GS115 (pSAOH5) and MC100-3 (pSAOH5) strains were generous gifts from Dr. J. M. Cregg, Keck Graduate Institute, Claremont, CA, USA. The mut ${ }^{+}$GS115 (pSAOH5) was integrated with a single copy of an $A O X 1$-lacZ fusion, pSAOH5. MC100-3 (pSAOH5) is isogenic to GS115 (pSAOH5), except for the defective $A O X 1$ and $A O X 2$ genes. Details of vector construction and transformations are reported elsewhere (6-8).

Determination of carbon source and cell concentration Ethanol and methanol were determined with a Shimadzu 17A gas chromatography using a Stabilwax $(0.53 \mathrm{~mm}, 2 \mu \mathrm{m}, 15 \mathrm{~m})$ fused silica capillary column with a polyethylene glycol stationary phase (Restek Corporation, Bellefonte, PA, USA). Helium was used as the carrier gas at a flow rate of $10 \mathrm{ml} / \mathrm{min}$, and $n$-propanol was used as an internal standard. Flame ionization detector and injector temperatures were maintained at $250^{\circ} \mathrm{C}$ and $220^{\circ} \mathrm{C}$, respectively. Column temperature was held at $40^{\circ} \mathrm{C}$ for $10 \mathrm{~min}$, and ramped to $100^{\circ} \mathrm{C}$ at the rate of $10^{\circ} \mathrm{C} / \mathrm{min}$. Glycerol and acetate concentrations were determined enzymatically (Biochimica Test combination; Boehringer Mannheim, Indianapolis, IN, USA). Turbidity of cells in the fermentation broth was measured with a spectrophotometer (DU-70 Beckman Inc., Fullerton, CA, USA) at $600 \mathrm{~nm}$.

Shake flask studies GS115 (pSAOH5) Mut $^{+}$was used for shake flask studies. Three carbon sources were examined, glyc- 
erol, ethanol and methanol, in minimal media. The carbon sources were present either individually or in combinations. All experiments were done in duplicate.

Inoculum was grown in $10-\mathrm{ml}$ test tubes of Minimal Glycerol (MGY) containing $1.34 \%$ yeast nitrogen base w/o amino acids (YNB), $1 \%$ glycerol and $410^{-5} \%$ biotin and subsequently used to inoculate $100 \mathrm{ml}$ of Minimal Media $\left(1.34 \%\right.$ YNB and $410^{-5 \%}$ biotin) plus $5 \mathrm{~g}^{-1}$ indicated carbon source in $500-\mathrm{ml}$ baffled shake flasks. The cultures were shaken in a rotary shaker at $200 \mathrm{rpm}$ and $30^{\circ} \mathrm{C}$. Carbon utilization and growth were monitored at specific time intervals.

For ethanol repression studies, the cultures were grown in $100 \mathrm{ml}$ of MGY to $\sim 5 \mathrm{OD}$. The culture was centrifuged at $2000 \times g$ for $10 \mathrm{~min}$, washed once with minimal media without carbon source and resuspended in the same amount of media. The control contained $5 \mathrm{~g} t^{-1}$ methanol and no ethanol while the other flask contained $5 \mathrm{~g} t^{-1}$ methanol and $10 \mathrm{mg} t^{-1}$ ethanol. External ethanol addition was continued for $3 \mathrm{~h}$ to maintain $10 \mathrm{mg}^{-1}$. Samples were taken every hour to determine methanol, cell density and $\beta$-galactosidase ( $\beta$-Gal) activity.

Acetate repression studies were identical to ethanol repression studies except different concentrations of acetate $(0,50,200$

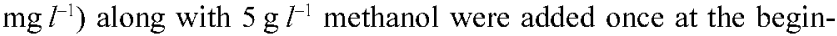
ning of the experiment. Samples were taken at 2-h intervals to determine methanol, cell density and $\beta$-Gal activity.

Fed-batch fermentation studies MC100-3 (pSAOH5) Mut was used in fed-batch fermentations using a Bioflo 3000 fermentor (New Brunswick Scientific, Edison, NJ, USA) with a 5-l vessel containing 3- $l$ of Basal Salts Media (9) with $4 \%$ glycerol. The $\mathrm{pH}$ of the medium was adjusted and controlled at 5.0 with $30 \%$ $\mathrm{NH}_{4} \mathrm{OH}$ solution. The fermentation temperature was maintained at $30^{\circ} \mathrm{C}$. The dissolved oxygen (D.O.) was maintained above $40 \%$ saturated air by supplementing the airflow with pure oxygen. Foaming of the culture broth was minimized by addition of antifoam Struktol J63 (Struktol Company, Stow, OH, USA). One hundred $\mathrm{ml}$ of overnight culture grown in MGY was used as an inoculum. After exhaustion of the initial glycerol, fed-batch feeding was initiated at $4 \mathrm{~g} / l / \mathrm{h}$. Methanol induction was initiated after $4 \mathrm{~h}$ of fed-batch feeding by injection of methanol so as to maintain a concentration of about $0.5 \%(\mathrm{v} / \mathrm{v})$ of culture volume. Methanol concentration was determined off-line and adjusted accordingly. The fed-batch feeds contain PTM1 trace salts solution (9) at a concentration of $12 \mathrm{ml} / /$. Acetate was added to a final concentration of $100 \mathrm{mg} l^{-1}$ at the start of induction. The control experiment did not include acetate addition.

Determination of $\beta$-galactosidase activity $\beta$-Gal activity was assayed by ONPG hydrolysis as described by Miller (10) and with the modification proposed by Guarente and Ptashne (11). The cells was permeabilized with chloroform and sodium dodecyl sulfate (SDS). Results were reported in Miller Units.

\section{RESULTS AND DISCUSSION}

\section{Growth of $\boldsymbol{P}$. pastoris in mixture of carbon sources}

$P$. pastoris was able to grow on all three carbon sources (glycerol, methanol and ethanol) as sole carbon and energy source (results not shown). Diauxic growth occurred when two of three carbon sources were present especially in ethanol-methanol and ethanol-glycerol mixtures (Fig. 1) with the glycerol being preferred over ethanol and methanol, ethanol being preferred over methanol.

During growth on a mixture of glycerol and ethanol, utilization of ethanol proceeded glycerol consumption and was accompanied by a transient accumulation of acetate, after the glycerol was completely exhausted. After this period, growth resumed with acetate as the carbon source (Fig. 1A). A diauxic growth pattern was also observed during growth on a mixture of ethanol and methanol, however ethanol was preferred over methanol. In this case, acetate accumulation was ten fold less $\left(2.0 \mathrm{~g} l^{1}\right.$ vs. $\left.0.2 \mathrm{~g} l^{1}\right)$ (Fig. 1B). A glycerol and methanol mixture did not follow a complete diauxic behavior with glycerol utilized first, with methanol utilization starting before all glycerol was consumed (Fig. 1C). This indicates that glycerol does not repress synthesis of methanol-utilizing enzymes to the same extent as ethanol, since
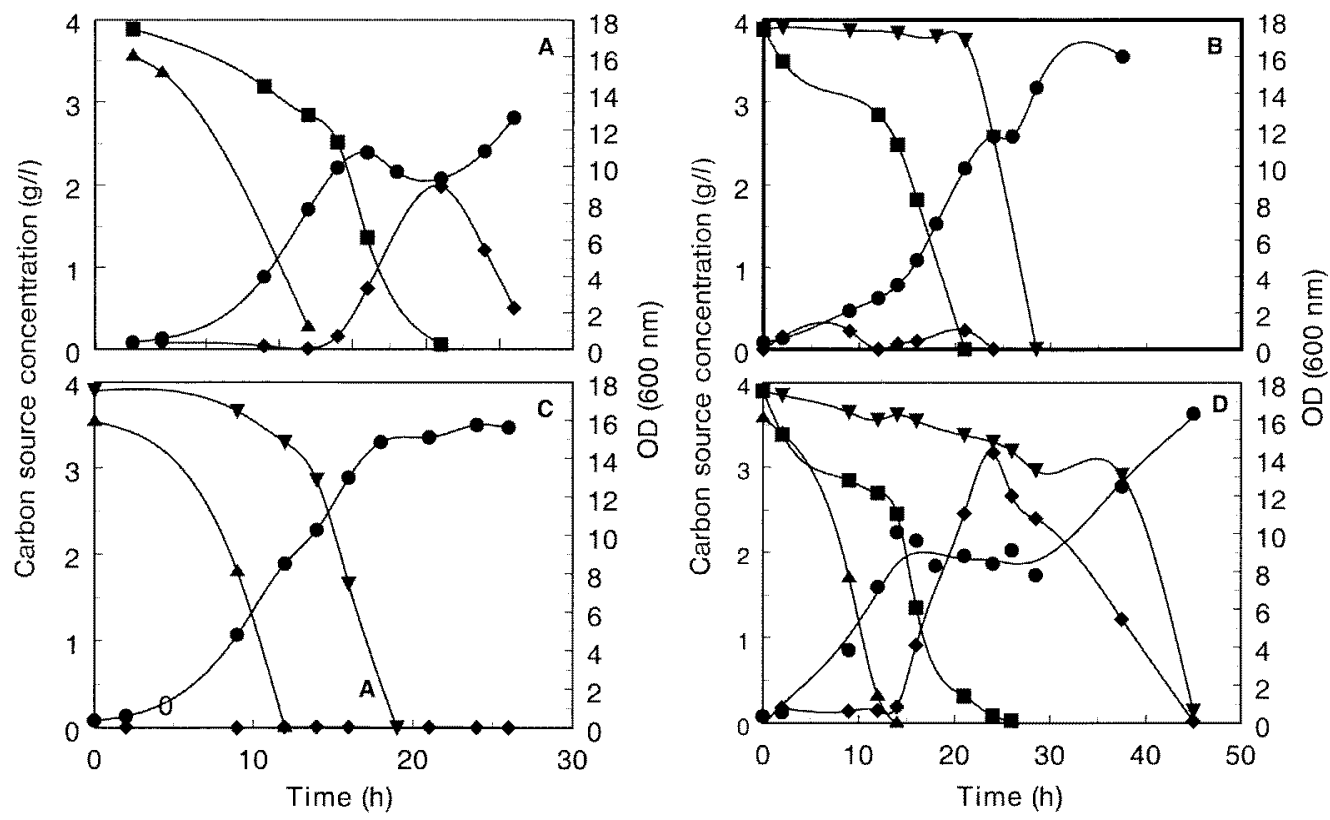

FIG. 1. Growth and Carbon utilization of P. pastoris. (A) ethanol-glycerol; (B) ethanol-methanol; (C) methanol-glycerol; (D) ethanol-methanolglycerol mixtures. Closed circle, OD; closed lozenge, acetate; closed triangle down, methanol; closed triangle up, glycerol; closed square, ethanol. 
methanol-utilizing enzymes appeared before the glycerol was consumed. When all three carbon sources were present, the order of utilization was glycerol, ethanol, acetate (which accumulated due to ethanol utilization) and methanol (Fig. 1D). Expression of $\beta$-Gal occurred only after methanol utilization (results not shown).

Although glycerol is a nonfermentable carbon source and $P$. pastoris is not considered a fermentative yeast, residual ethanol does accumulate during Pichia fermentation when a high feed-rate of glycerol was used. This phenomenon has been reported previously and its mechanism remains unexplored $(4,5,9,12)$.

At this point we assume that ethanol is metabolized to acetaldehyde and then to acetate, which is assimilated into acetyl-CoA as described for Hansenula polymorpha (13) and Pichia methanolica (14). The rate-limiting step in ethanol utilization appears to be the assimilation of acetate, based on the accumulation of acetate after the depletion of ethanol.

Repression of $\beta$-galactosidase production by ethanol and acetate Results of methanol utilization and $\beta$-Gal expression in the presence of ethanol are shown in Fig. 2. Addition of external ethanol for three hours prolonged initiation of methanol induction of the $A O X I$ promoter. Addition of ethanol also supported growth, which is evident by the diauxic growth shown in Fig. 2. Even an ethanol concentration of $10 \mathrm{mg} l^{1}$ repressed the $A O X I$ promoter and supported the growth.

Depending on the amount of acetate added during shake flask studies, acetate resulted in extension of the adaptation time to methanol indicating repression of methanol-utilization enzymes. It should be noted that acetate addition to the shake flasks was done only at the beginning of the induction; however, ethanol addition was continued for $3 \mathrm{~h}$ maintaining the desired concentrations. Addition of $10 \mathrm{mg} l^{1} \mathrm{ac}-$ etate had no effect on methanol utilization/ $\beta$-Gal expression suggesting this concentration of acetate was quickly utilized (results not shown). However, $50 \mathrm{mg} l^{1}$ acetate addition did

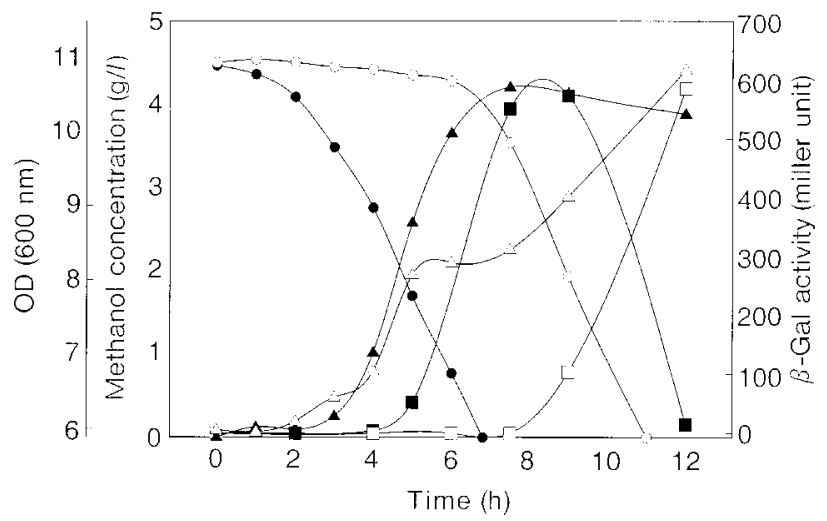

FIG. 2. Effect of ethanol on the $\beta$-gal expression and methanol utilization. GS115 (pSAOH5) strain was grown in MGY to $\sim 5 \mathrm{OD}_{600}$. The cells were collected, resuspended in Minimal Media containing $0.5 \%$ methanol. Ethanol $\left(10 \mathrm{mg} l^{1}\right)$ was added to experimental shake flask externally, for $3 \mathrm{~h}$. In a control experiment, no ethanol was added. Closed circle, methanol (control); open circle, methanol (ethanol); closed triangle, OD (control); open triangle, OD (ethanol); closed square, $\beta$-Gal (control); open square, $\beta$-Gal (ethanol). delay $\beta$-gal expression and methanol utilization by $2 \mathrm{~h}$ (Fig. 3). In one experiment $50 \mathrm{mg} l^{1}$ of acetate and $100 \mathrm{mg} l^{1}$ ethanol were added at the same time. The ethanol was converted in a molar ratio to acetate within $2 \mathrm{~h}$ (results not shown). When $200 \mathrm{mg} l^{1}$ acetate was added, methanol utilization and $\beta$-gal expression was delayed $7 \mathrm{~h}$ even though there was no acetate in the broth after $2 \mathrm{~h}$.

We next conducted a fed-batch fermentation experiment to determine the effect of ethanol and acetate on $\beta$-Gal expression in a Mut strain, defective in $A O X I$ and $A O X 2$ genes. The Mut strain was chosen to keep the methanol concentration constant during the fermentation since this strain cannot utilize methanol. The control experiment was run as described in the material and methods section excluding acetate addition. In an experimental run, $100 \mathrm{mg} l^{1}$ acetate was injected at the start of methanol induction. Attempts were made to maintain the acetate concentration in the fermentor at $100 \mathrm{mg} l^{1}$ by adding acetate. Unfortunately, at high cell densities (O.D. $>100$ ) acetate was assimilated very rapidly and the fermentor maintained a basal level of $10 \mathrm{mg} l^{1}$ (the same level of acetate that had no effect on shake flask expression). A spike of $250 \mathrm{mg} l^{1}$ of acetate leveled off the growth and $\beta$-Gal expression (Fig. 4) contrary to the control experiment (results not shown). Although the acetate was assimilated in $15 \mathrm{~min}$, its effect on biomass production and $\beta$-gal expression lasted about $5 \mathrm{~h}$. During the spike, ethanol concentration increased from 10 $\mathrm{mg} l^{1}$ to $40 \mathrm{mg} l^{1}$ and then was quickly assimilated. Since there is no available information on the alcohol dehydrogenase enzyme(s) or gene(s) of $P$. pastoris, it is difficult to speculate why a spike of acetate on limited-glycerol grown culture resulted in ethanol accumulation. When $250 \mathrm{mg} l^{1}$ ethanol was injected in place of acetate, similar results were observed. Ethanol was assimilated in $15 \mathrm{~min}$ and acetate appeared and reached to a basal level of $10 \mathrm{mg} l^{1}$ in the fermentation broth. Two-hour delays in $\beta$-gal expression and biomass productions were also observed (results not shown).

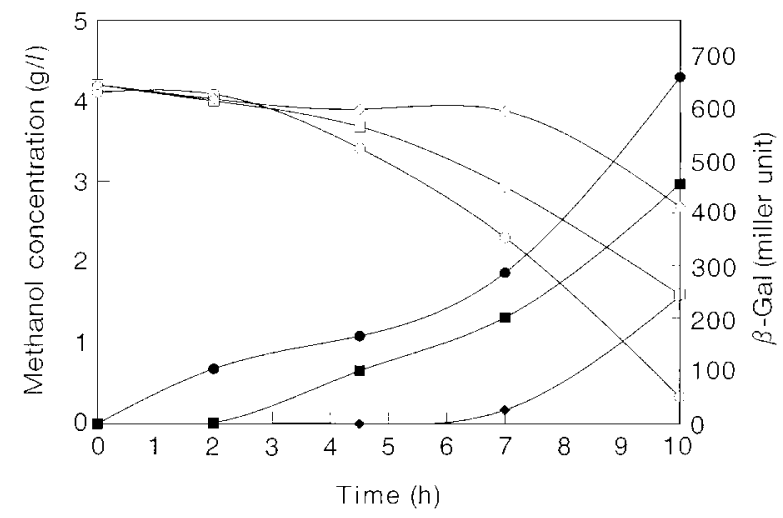

FIG. 3. Effect of acetate on $\beta$-gal production and methanol utilization. GS115 (pSAOH5) strain was grown in MGY to $\sim 5 \mathrm{OD}_{600}$. The cells were collected, resuspended in Minimal Media containing $0.5 \%$ methanol. Acetate $\left(0,50,200 \mathrm{mg} l^{1}\right)$ was added to experimental shake flask externally at the beginning of the experiment. Closed circle, $\beta$-Gal (control); closed square, $\beta$-Gal (50 $\mathrm{mg} l^{1}$ acetate); closed lozenge, $\beta$ Gal (200 $\mathrm{mg} l^{\prime}$ acetate); open circle, methanol (control); open square, methanol (50 $\mathrm{mg} l^{1}$ ); open lozenge, methanol (200 $\mathrm{mg} l^{1}$ acetate). 


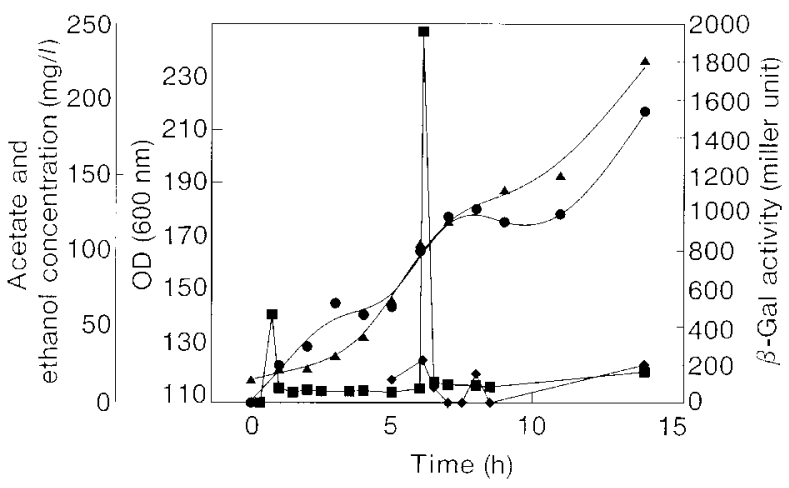

FIG. 4. Effect of acetate on $\beta$-Gal production in fed-batch fermentation. MC100-3 (pSAOH5) strain was grown on BSM. Batch phase was on $4 \%$ glycerol as carbon source. Fed-batch glycerol feeding $(4 \mathrm{~g} / \mathrm{l} / \mathrm{h})$ continued for $4 \mathrm{~h}$. Induction phase was started with adding $0.5 \%$ methanol. Acetate $\left(100 \mathrm{mg} l^{1}\right.$ and $\left.250 \mathrm{mg} l^{1}\right)$ at 0 and $6 \mathrm{~h}$, respectively. Closed circle, OD; closed triangle, $\beta$-Gal; closed square, acetate; closed lozenge, ethanol.

Regulation of methanol metabolism in methylotrophs is a very complex process including control of synthesis and activation of the corresponding enzymes as well as their degradation (2). Synthesis of methanol metabolizing enzymes is induced by methanol, formaldeyde and formate $(2,15$, 16). Investigations on $A O X$ regulation revealed that alcohol oxidase activity is reduced by glucose and ethanol through two-regulation mechanism, catabolite repression and catabolite inactivation. The former involves the control of enzyme synthesis and the latter involves the inactivation or degradation of the enzymes.

The mechanism of ethanol repression in P. pastoris has not yet been studied thoroughly although there have been sporadic reports describing ethanol repression mutants in and $P$. pinus MH4 ( $P$. methanolica). H. polymorpha and $P$. methanolica are very closely related methylotrophic yeasts that share high homology at amino acid level of AOX protein $(69 \%)(17)$.

A mutant of $P$. methanolica resistant to allyl alcohol with decreased alcohol dehydrogenase activity was isolated (18). The mutant $(a d h I)$ showed AOX activity when cultivated in medium with ethanol even in the absence of methanol.

The effect of ethanol and acetate on repression and inactivation of alcohol oxidase and catalase was studied in mutants of $P$. methanolica (19). It was found that ethanol repression of the $A O X$ in isogenic strains carrying mutations in genes encoding acetyl CoA synthatase (acsl, acs 2 and $a c s 3)$ and isocitrate lyase (icl 1$)$, malate synthase ( $m l s 1)$, phosphoenolpyruvate carboxykinase ( $p c k 1)$ and malic enzyme ( $m d d 1$ ) was not impaired, but mutations in alcohol dehydrogenase $(a d h 1, a d h 2)$ and acetaldehyde dehydrogenase $($ aldX) impaired the ethanol induced repression of alcohol oxidase and catalase. On the other hand, acetate normally repressed alcohol oxidase and catalase in all mutants. It was suggested by Sibirny (19) that acetate was the true effector (corepressor) which evokes catabolite repression of $\mathrm{C}_{1}$ metabolic enzymes in the medium with ethanol.

$P$. methanolica and $P$. pastoris are very closely related yeasts and their methanol utilization pathway are similar. It is likely that the $A O X I$ and $A U G 1$ genes in $P$. pastoris and $P$. methanolica, respectively, are regulated by the same regulatory pathway. Our results also suggest that acetate, which is a product of ethanol utilization pathway, causes the repression of $A O X 1$ promoter since unless acetate was consumed no $\beta$-gal production observed. We have identified two proteins that bind to the $A O X I$ promoter in the cell extract of $P$. pastoris grown in methanol/ethanol and methanol/glycerol mixture by mobility gel shift assay (unpublished data, Inan, $M$ and Meagher, M. M). One of these proteins could be a repressor protein since the deletion of the site on which the protein binds increase strength of the promoter compared to native one. We are in the process of purifying of these proteins and constructing deletion mutants of genes coding the regulatory proteins to elucidate the catabolite repression mechanism.

In conclusion, ethanol and acetate at $10-50 \mathrm{mg} l^{1}$ inhibits $\beta$-Gal expression under shake flask conditions, however, ethanol and acetate at $10 \mathrm{mg} l^{1}$ did not effect $\beta$-Gal expression in fed-batch culture contrary to shake flask results. Although our studies did not determine the inhibitory level of ethanol and acetate in fed-batch fermentation conditions of $P$. pastoris, we conclude that acetate and ethanol levels in the fermentor should be closely monitored to achieve higher productivity. Since this study revealed the importance of residual by-products, future studies will determine inhibitory levels under fermentation conditions by using chemostat cultures to maintain acetate and ethanol concentrations constant, and proteins that involves in ethanol/acetate repression of the $A O X I$ promoter.

\section{ACKNOWLEDGMENT}

The authors wish to thank Professor Robert W. Hutkins, Department of Food Science and Technology, University of NebraskaLincoln, for critical reading of this manuscript.

\section{REFERENCES}

1. Cereghino, G. P. L. and Cregg, J. M.: Application of yeast in biotechnology: protein production and genetic analysis. Curr. Opin. Biotechnol., 10, 422-427 (1999).

2. Veenhuis, M., van Dijken, J. P., and Harder, W.: The significance of peroxisomes in the metabolism of one-carbon compounds in yeasts. Adv. Microbiol. Physiol., 24, 1-52 (1983).

3. Stratton, J., Chiruvolu, V., and Meagher, M. M.: High cell-density fermentation, p. 107-120. In Higgins, D. R. and Cregg, J. M. (ed.), Pichia protocols. Humana Press Inc., New Jersey (1998).

4. Brierley, R. A., Bussineau, C., Kosson, R., Melton, A., and Siegel, R.S.: Fermentation development of recombinant Pichia pastoris expressing the heterologous gene: bovine lysozyme. Ann. NY Acad. Sci., 589, 350-362 (1990).

5. Chiruvolu, V., Cregg, J. M., and Meagher, M. M.: Recombinant protein production in an alcohol oxidase-defective strain of Pichia pastoris in fed-batch fermentations. Enzyme Microb. Technol., 21, 277-283 (1997).

6. Cregg, J. M., Madden, K. R., Barringer, K. J., Thill, G. P., and Stillman, C.A.: Functional characterization of the two alcohol oxidase genes from the yeast Pichia pastoris. Mol. Cell. Biol., 9, 1316-1323 (1989).

7. Cregg, J. M. and Madden, K. R.: Development of yeast transformation systems and construction of methanol-utilization-defective mutants of Pichia pastoris by gene disruption. 
Biol. Res. Ind. Yeast, 2, 1-19 (1987).

8. Tschopp, J. F., Brust, P. F., Cregg, J. M., Stillman, C. A., and Gingeras, T. R.: Expression of the lac $Z$ gene from two methanol-regulated promoters in Pichia pastoris. Nucleic Acids Res., 15, 3859-3876 (1987).

9. Chiruvolu, V., Eskridge, K. M., Cregg, J.M., and Meagher, M. M.: Effects of glycerol concentration and $\mathrm{pH}$ on growth of recombinant Pichia pastoris yeast. Appl. Biochem. Biotechnol., 75, 163-173 (1999).

10. Miller, J. H.: Assay of $\beta$-galactosidase, p. 352-355. In Miller, J.H. (ed.), Experiments in molecular genetic. Cold Spring Harbor Laboratory, New York (1972).

11. Guarente, L. and Ptashne, M.: Fusion of Escherichia coli lacZ to the cytochrome c gene of Saccharomyces cerevisiae. Proc. Natl. Acad. Sci. USA, 78, 2199-2203 (1981).

12. Inan, M., Chiruvolu, V., Eskridge, K. M., Vlasuk, G.P., Dickerson, K., Brown, S., and Meagher, M. M.: Optimization of temperature-glycerol-pH conditions for a fed-batch fermentation process for recombinant hookworm (Ancylostoma canimim) anticoagulant peptide (AcAP-5) production by Pichia pastoris. Enzyme Microb. Technol., 24, 438-445 (1999).

13. Sulter, G. J., Klei, I. J. v.-d., Schanstra, J. P., Harder, W., and Veenhuis, M.: Ethanol metabolism in a peroxisomedeficient mutant of the yeast Hansenula polymorpha. FEMS Microbiol. Lett., 82, 297-302 (1991).

14. Tolstorukov, I. D. E. B., Benevolensky, B. D., Titorenko,
V. I., and Sibirny, A. A.: Mutans of methylotrophic yeast Pichia pinus defective in C2 metabolism. Yeast, 5, 179-186 (1989).

15. Sibirnyi, A. A., Titorenko, V. I. D. E. B., and Tolstorukov, I.: Multilicity of mechanisms of carbon catabolite repression involved in the synthesis of alcohol oxidase in the methylotrophic yeast Pichia pimus. Yeast, 3, 233-241 (1987).

16. Egli, T., Dijken, J.P.v., Veenhuis, M., Harder, W., and Fiechter, A.: Methanol metabolism in yeasts: regulation of the synthesis of catabolic enzymes. Arch. Microbiol., 124, 115-121 (1980).

17. Raymond, C. K., Bukowski, T., Holderman, S. D., Ching, A. F., Vanaja, E., and Stamm, M. R.: Development of the methylotrophic yeast Pichia methanolica for the expression of the 65 kilodalton isoform of human glutamate decarboxylase. Yeast, 14, 11-23 (1998).

18. Titorenko, V.I., Motruk, O. M., Efremov, B. D., Petrushko, V. I., Teslyar, G. E., Kulachkovskii, A. R., Sibirnyi, A. A., and Tolstorukov, I. I.: Selection and characterization of strains of the methylotrophic yeast Pichia pimus with mutations in the alcohol dehydrogenase and formaldehyde reductase genes. Sov. Genet., 26, 1144-1151 (1991).

19. Sibirny, A. A.: Genetic control of methanol and ethanol metabolism in the yeast Pichia pinus, p. 545-555. In Heslot, H. (ed.), Proc 6th Int. Symp. on Genetics of Ind. Microorg., vol. 1. Soc. Franc. Microbiol., Strasbourg, France (1990). 